\title{
Correlation of Capute Scores with CD4 Count among Human Immunodeficiency Virus-infected Children in Sanglah Hospital, Bali, Indonesia
}

\author{
I. Nyoman Supadma ${ }^{1}$, Putu Indah Budiapsari ${ }^{2 \star}$, Ketut Dewi Kumara Wati ${ }^{3}$, I. Wayan Dharma Artana $^{3}$ \\ ${ }^{1}$ Department of Paediatric, Famili Husada Hospital, Gianyar, Bali, Indonesia; ${ }^{2}$ Department of Microbiology and Parasitology, \\ Faculty of Medicine and Health Sciences, Warmadewa University, Denpasar, Indonesia; ${ }^{3}$ Department of Child Health, Sanglah \\ Hospital, Udayana University, Bali, Indonesia
}

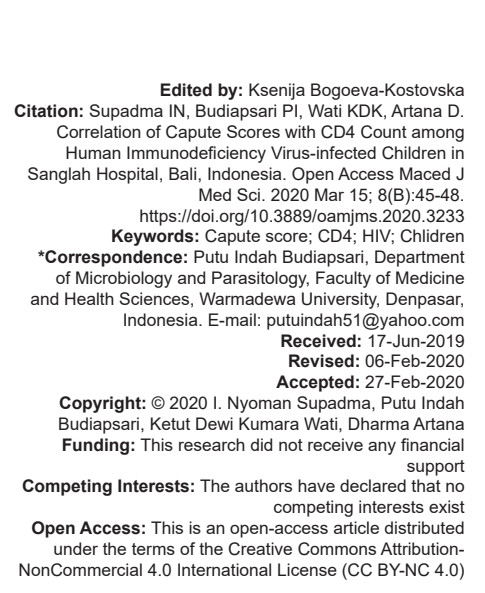

\begin{abstract}
BACKGROUND: Cognitive, motoric, and language development in a human immunodeficiency virus (HIV)-infected child is an important issue that affects developmental milestone and quality of life. The effect of HIV infection on cognitive function must be detected early to prevent delayed cognitive, motoric, and language function.

AIM: This study aimed to assess the correlation of cognitive scores with CD4 count among HIV-infected children in pediatrics polyclinic Sanglah Hospital, Bali.

METHODS: This cross-sectional study recruited 68 HIV-infected children age 0-36 months old as participants Cognitive score was assessed using Cognitive Adaptive Test/Clinical Linguistic and Auditory Milestone Scale (CAT/ CLAMS) scores and HIV status, and CD4 count was obtained from the medical record.

RESULTS: The result showed that mean of CD4 count among subject was $29.85 \mathrm{cells} / \mathrm{mm}^{3}$, there was positive correlation between CAT scores with CD4 count $(r=0.33, p=0.006)$ and also between CLAMS scores with CD4 count $(r=0.307, p=0.01)$.

CONCLUSION: It can be concluded that CD4 count correlated with Capute scores on HIV-infected children.
\end{abstract}

\section{Introduction}

The human immunodeficiency virus (HIV) is a lymphotropic and neurotrophic retrovirus that belongs to the Lentiviridae subfamily, causing a slow and chronic infection [1], affecting several organs and systems. Among them, the central nervous system is frequently affected, causing delays in neurodevelopment that can be one of the first symptoms of the disease [1], [2], [3], [4], [5], [6]. Children with vertically transmitted HIV can develop rapid or slow progressive psychoneuromotor development deceleration, which can begin as soon as six months of age. Other children may have static encephalopathy [1], [2], [3], [4], [5], [6].

Abnormalities and neurocognitive development among HIV-infected children become very important since the HIV cases in children were first reported in 1980 in the United States [1]. HIV causes serious cell damage due to symptoms of acquired immunodeficiency syndrome. One of the serious cell damage is found in the brain that manifested into neurocognitive development. Symptoms were found to vary from moderate to severe. Moderate symptoms include abnormal muscle tone, while severe symptoms include progressive developmental delay and loss of ability in the previous milestone [2]. HIV infection in children can cause brain damage in the form of neurocognitive disorders. Untreated HIV-infected children are associated with the development of cognitive deficits, motoric, language, and psychological impairments [3]. Early developmental delays in language and cognitive abilities can affect various functions in daily life. Early identification and intervention can prevent cognitive impairment and language [4]. The cause of the problems is unclear, whether the impact of HIV itself in decreasing the mitochondrial DNA as found in HIV cases using antiretroviral therapy. One of the early predictor factors of worsen symptom of HIV infection are CD4 count [5].

The Cognitive Adaptive Test/Clinical Linguistic and Auditory Milestone Scale (CAT/CLAMS) was designed for use by primary pediatric health-care providers to screen children for cognitive delay using minimal equipment in a shorter time (usually 15-20 min) [4]. CAT/CLAMS has been demonstrated 
in normal children as well as high-risk groups of developmental delayed children between 1 and 36 months of age [7], [8]. This study aimed to assess the correlation of Capute score with CD4 count among HIVinfected children in Sanglah Hospital, Bali, Indonesia.

\section{Methods}

This research was conducted in Sanglah Hospital Bali from December 2013 to May 2014. The subjects were collected by consecutive sampling until we reached the minimum number of samples. The cross-sectional analytic study was used to assess the correlation of Capute scores with CD4 count among HIVinfected children. Capute scores consist of two tests Cat and Clams tests will be performed to get Capute scores, and CD4 count was assessed by flow cytometry and HIV status was obtained from serologic test that recorded in the medical record. The Capute scores then classified into normal (>85), suspect (75-85), and mental retardation $(<75)$. Inclusion criteria in this study were 0-36 months HIV-infected children who visit Pediatrics Polyclinic, Sanglah Hospital and got assignment from the parent by informed consent. Subject and the subject's parents refused to participate in the study, subjects with other comorbid diseases, and subject whom loss to follow-up will be excluded from the study.

\section{Ethical consideration}

Ethical clearance was obtained from the Department of Research Development of Sanglah Hospital, Faculty of Medicine, Udayana University.

\section{Results}

During the study, there were 68 samples as the HIV group and 68 samples were selected as the control group. The characteristics of the study subjects are shown in Table 1. Almost the HIV group was male $37(54.5 \%)$, but in the control group found predominantly female subjects of 38 (55.9\%). Both HIV and control group were almost in 12-24-monthold 31 (48.4\%) and 33 (51.6\%). Almost the HIV group was in the asymptomatic stage. The status of milestone development in the two groups was almost within normal limits. Clinical manifestations that occur in the HIV group were mostly without complaint.

The result of the correlation test showed average of CD4 count was 29.85 cells $/ \mathrm{mm}^{3}$, mean of DQ CAT scores was $90.95 \pm 10.8$, and mean of $D Q$ CLAMS scores $89.22 \pm 6.9$.
Table 1: Characteristics of the subjects

\begin{tabular}{lll}
\hline Characteristics of the subjects & $\begin{array}{l}\text { Human immunodeficiency virus group } \\
\mathrm{n}(\%)\end{array}$ & $\begin{array}{l}\text { Control group } \\
\mathrm{n}(\%)\end{array}$ \\
\hline Gender & $37(54.5)$ & $30(44.1)$ \\
Male & $31(45)$ & $38(55.9)$ \\
Female & & \\
Age (months) & $14(45.2)$ & $17(54.8)$ \\
$0-12$ & $31(48.4)$ & $33(51.6)$ \\
$13-24$ & $23(56.1)$ & $18(43.9)$ \\
$25-36$ & & \\
Stadium of infection & $39(57.4)$ & $0(0)$ \\
Asymptomatic & $14(20.6)$ & $0(0)$ \\
Mild & $13(19.1)$ & $0(0)$ \\
Moderate & $2(2.9)$ & $0(0)$ \\
Severe & $1(1.5)$ & $0(0)$ \\
Developmental state & $2(2.29)$ & $0(0)$ \\
Mental retardation & $40(58.8)$ & $64(94.1)$ \\
Delayed speech & $25(36.8)$ & $4(5.9)$ \\
Normal & & \\
Suspect & $2(2.9)$ & $0(0)$ \\
Clinical manifestations & $1(1.5)$ & $0(0)$ \\
GIT (diarrhea) & $17(25)$ & $0(0)$ \\
GIT (vomiting) & $1(1.5)$ & $0(0)$ \\
Acute respiratory infection & $0(0)$ \\
Hyperpigmentation on skin & $42(61.8)$ & $0(0)$ \\
No symptom & $5(7.4)$ & \\
Wasting syndrome & & \\
\hline GIT: Gastro Intestinal Tract. & &
\end{tabular}

We included all of CD4 count, DQ CAT, and DQ Clams scores in HIV-infected children to get mean then tested by Pearson's correlation test. The result showed a positive correlation of CD4 count with $\mathrm{DQ}$ Cat and DQ Clams, as described in Table 2. It means CD4 count significantly correlated with Capute scores.

Table 2: Pearson's correlation of CD4 with Capute score in human immunodeficiency virus-infected children

\begin{tabular}{lcclll}
\hline Variable & Min. & Max. & Mean \pm SD & $r$ & $p$ \\
\hline CD4 count & 17.50 & 40.70 & $29.85 \mathrm{celll} / \mathrm{mm}^{3}$ & & \\
DQ CAT scores & 72.30 & 145.0 & $90.95 \pm 10.8$ & 0.331 & 0.006 \\
DQ CLAMS scores & 71.50 & 110.0 & $89.22 \pm 6.9$ & 0.307 & 0.011 \\
\hline CAT: Cognitive Adaptive Test, CLAMS: Clinical Linguistic and Auditory Milestone Scale.
\end{tabular}

As shown in Table 3, subjects with CD4 $<25$ cells $/ \mathrm{mm}^{3}$ tend to be mental retardation, delayed speech, and suspect for cognitive impairment. in the contrary subject with CD4 $>25 \mathrm{cell} / \mathrm{mm}^{3}$ there were no evidence of mental retardation or delayed speech, and almost in normal cognitive performance in the contrary.

Table 3: Cognitive state based on CD4 count

\begin{tabular}{lllll}
\hline Category of CD4 & Cognitive state & & \\
\cline { 2 - 5 } count & Mental retardation & delayed speech & Normal & Suspect \\
\hline$<25$ cells $/ \mathrm{mm}^{3}$ & 1 & 2 & 4 & 8 \\
$>25$ cells $/ \mathrm{mm}^{3}$ & 0 & 0 & 37 & 16 \\
Total & 1 & 2 & 41 & 24 \\
\hline
\end{tabular}

\section{Discussion}

CD4 count was the easiest predictor factor of the degree of HIV symptoms, and this study showed its positive correlation with Capute score. In line with previous research obtained that there was a positive correlation between cognitive disorders with CD4 levels [9], [10], [11]. Positive correlation also found between CAT scores and CD4 count $(r=0.418$ and $p=0.01$ ). Significant correlation also found between Clams scores with CD4 count $(r=0.529$ and $p=0.01)$. These results indicate that the lower of CD4 count and 
the lower CAT/Clams scores. CD4 plays importance role in cognitive function of HIV-infected children, subject with CD4 $<25$ cells $/ \mathrm{mm}^{3}$ had lower cognitive performance than subject with CD4 $><25$ cells $/ \mathrm{mm}^{3}$. As described previously by Vanprapar et al., microglial cells in neuron play a role in cognitive performance of HIV person [2], [12], [13]. In contrary to a previous study by lgumbor et al., there were little or no associations between the biomedical markers (CD4 count and viral load) and cognitive indicators. However, the quality of life tended to increase with increase in the CD4 cell count [14], [15], [16], [17], [18], [19].

\section{Conclusion}

From this study, it can be concluded that Capute scores are significantly correlated with CD4 count. The lower the CD4 count, the lower the cognitive score. Further study should be conducted to analyze the mechanism of HIV infection affect cognitive performance on HIV-infected children before early intervention to prevent cognitive impairment on HIVinfected children.

\section{References}

1. Van Rie A, Harrington PR, Dow A, Robertson K. Neurologic and neurodevelopmental manifestations of pediatric HIVIAIDS: A global perspective. Eur J Paediatr Neurol. 2007;11(1):1-9. https://doi.org/10.1016/j.ejpn.2006.10.006 PMid: 17137813

2. Vanprapar N, Kongstan N, Tritilanant P, Kottapat U, Durier $\mathrm{Y}$, Tritilanant $S$. Developmental screening by the cognitive adaptive test/clinical linguistic and auditory milestone scale (CAT/CLAMS) in HIV-infected children. J Med Assoc Thai. 2005;88 Suppl 8:S211-4.

PMid: 16856442

3. Tahan TT, Bruck I, Burger M, Cruz CR. Neurological profile and neurodevelopment of 88 children infected with HIV and 84 seroreverter children followed from 1995 to 2002. Braz J Infect Dis. 2006;10(5):322-6. https://doi.org/10.1590/ s1413-86702006000500004

PMid:17293919

4. Andrade AS, Deutsch R, A Celano S, Duarte NA, Marcotte TD, Umlauf $A$, et al. Relationships among neurocognitive status, medication adherence measured by pharmacy refill records, and virologic suppression in HIV-infected persons. J Acquir Immune Defic Syndr. 2013;62(3):282-92. https://doi.org/10.1097/ qai.0b013e31827ed678

PMid:23202813

5. Thomaidis L, Bertou G, Critselis E, Spoulou V, Kafetzis DA, Theodoridou M. Cognitive and psychosocial development of HIV pediatric patients receiving highly active anti-retroviral therapy: A case-control study. BMC Pediatr. 2010;10:99. https:// doi.org/10.1186/1471-2431-10-99
6. Caravale B, Tozzi C, Albino G, Vicari S. Cognitive development in low risk preterm infants at 3-4 years of life. Arch Dis Child Fetal Neonatal Ed. 2005;90(6):F474-9.

PMid:15956096

7. Masyeni S, Sintya E, Megawati D, Sukmawati NM, Budiyasa DG Aryastuti SA, et al. Evaluation of antiretroviral effect on mitochondrial DNA depletion among HIV-infected patients in Bali. HIV AIDS (Auckl). 2018;10:145-50. https://doi.org/10.2147/ hiv.s166245

PMid:30104903

8. Bruck I, Tahan TT, Cruz CR, Martins LT, Antoniuk SA, Rodrigues $\mathrm{M}$, et al. Developmental milestones of vertically HIV infected and seroreverters children: Follow up of 83 children. Arq Neuropsiquiatr. 2001;59(3-B):691-5. https://doi.org/10.1590/ s0004-282x2001000500007

PMid:11593266

9. Lindsey JC, Malee KM, Brouwers P, Hughes MD, PACTG $219 \mathrm{C}$ Study Team. Neurodevelopmental functioning in HIV-infected infants and young children before and after the introduction of protease inhibitor-based highly active antiretroviral therapy. Pediatrics. 2007;119(3):e681-93. https://doi.org/10.1542/ peds.2006-1145

PMid:17296781

10. Nakasujja N, Allebeck P, Agren H, Musisi S, Katabira E. Cognitive dysfunction among HIV positive and HIV negative patients with psychosis in Uganda. PLoS One. 2012;7(9):e44415. https://doi. org/10.1371/journal.pone.0044415

PMid:22970214

11. Khairunisa $S Q$, Masyeni $S$, Witaningrum $A M$, Yunifiar $M Q$, Indriati DW, Kotaki T. Genotypic characterization of human immunodeficiency virus Type 1 isolated in Bali Indonesia in 2016. HIV AIDS Rev. 2018;17:81-90. https://doi.org/10.5114/ hivar.2018.76375

12. Kerr SJ, Puthanakit T, Vibol U, Aurpibul L, Vonthanak S, Kosalaraksa P, et al. Neurodevelopmental outcomes in HIVexposed-uninfected children versus those not exposed to HIV. AIDS Care. 2014;26(11):1327-35. https://doi.org/10.1080/0954 0121.2014 .920949

PMid:24878112

13. Ngoma MS, Hunter JA, Harper JA, Church PT, Mumba S, Chandwe $\mathrm{M}$, et al. Cognitive and language outcomes in HIV-uninfected infants exposed to combined antiretroviral therapy in utero and through extended breast-feeding. AIDS. 2014;28 Suppl 3:S323-30. https://doi.org/10.1097/ qad. 0000000000000357 PMid:24991905

14. Igumbor J, Stewart A, Holzemer W. Comparison of the healthrelated quality of life, CD4 count and viral load of AIDS patients and people with HIV who have been on treatment for 12 months in rural South Africa. SAHARA J. 2013;10(1):25-31. https://doi. org/10.1080/17290376.2013.807070 PMid:23777555

15. Nozyce ML, Lee SS, Wiznia A, Nachman S, Mofenson LM, Smith ME, et al. A behavioral and cognitive profile of clinically stable HIV-infected children. Pediatrics. 2006;117(3):763-70. https://doi.org/10.1542/peds.2005-0451 PMid:16510656

16. Puren A, Gerlach JL, Weigl BH, Kelso DM, Domingo GJ Laboratory operations, specimen processing, and handling for viral load testing and surveillance. J Infect Dis. 2010;201 Suppl 1:S27-36. https://doi.org/10.1086/650390 PMid:20225943

17. Rice ML, Buchanan AL, Siberry GK, Malee KM, Zeldow B, Frederick $\mathrm{T}$, et al. Language impairment in children perinatally infected with HIV compared to children who were HIV-exposed 
and uninfected. J Dev Behav Pediatr. 2012;33(2):112-23. https:// doi.org/10.1097/dbp.0b013e318241ed23

PMid:22179050

18. Wojna V, Skolasky RL, Hechavarría R, Mayo R, Selnes O, McArthur JC, et al. Prevalence of human immunodeficiency virusassociated cognitive impairment in a group of Hispanic women at risk for neurological impairment. J Neurovirol. 2006;12(5):356-64. https://doi.org/10.1080/13550280600964576

PMid: 17065128

19. Witaningrum $A M$, Khairunisa $S Q$, Ueda $S$, Yunifiar $M Q$, Indriati DW, Kotaki T, et al. Viral subtyping of HIV-1 derived from infected, drug-naïve individual in Jakarta, Indonesia. IOP Conf Ser. 2018;434:012321. https:// doi.org/10.1088/1757-899x/434/1/012321 